\title{
LAS ORDENANZAS DE LA GOBERNACIÓN DE CATALUÑA
} (1399)

\author{
José Vicente CABEZUelo Pliego \\ Universidad de Alicante
}

\begin{abstract}
SUMARIO
1. El gobernador.- 2. El asesor.- 3. El abogado fiscal.- 4. El "reebedor dels emoluments".- 5. El procurador fiscal.- 6. El escribano.- 7. El alguacil.- 8. Los porteros.- 9. Los correos.- Apéndice documental.
\end{abstract}

En algunos de nuestros trabajos acerca de la Procuración/Gobernación valenciana ${ }^{1}$ hemos señalado la escasa, cuando no nula, atención que la historiografía de los estados que componían la antigua Corona de Aragón ha dedicado a una institución del calado y la importancia de la arriba mencionada. Es un hecho curioso, constatábamos, que mientras que en el ámbito castellano los estudios institucionales se han promovido de manera notable, siendo a tal caso merinos, adelantados o corregidores figuras perfectamente conocidas en cuanto a historiadas, la Corona de Aragón no ha conocido de una orientación investigadora paralela. Ni Aragón, ni Cataluña, ni Valencia, ni Mallorca poseen líneas abiertas que conduzcan a investigaciones modernas sobre las principales magistraturas de sus respectivos territorios, con las

'J.V. Cabezuelo Pliego, Reflexiones en torno al oficio de la Procuración como instrumento de la acción regia para el gobierno político del reino de Valencia, "Anales de la Universidad de Alicante. Historia Medieval", 10 (Alicante, 1994-1995), pp. 21-34; ID., Poder público y administración territorial en el reino de Valencia, 1239-1348. El oficio de la Procuración, Valencia, 1998; ID., La Curia de la Procuración. Estructura de una magistratura medieval valenciana, Alicante, 1998.

"Anuario de Estudios Medievales", 29 (1999) 
lógicas excepciones. Aunque sí Cerdeña, donde el análisis de las instituciones políticas, jurídicas, económicas y financieras de la isla han sido, y lo siguen siendo, estudiadas con profusión ${ }^{2}$, ámbito en el que destacan en el estudio de la Gobernación G. Olla Repetto ${ }^{3}$ y M. Costa i Paretas ${ }^{4}$. La única obra de conjunto existente acerca de la Gobernación en la Corona de Aragón pertenece a J. Lalinde Abadía, trabajo que a pesar de haber conocido el paso de más de tres décadas sigue siendo punto de referencia inexcusable ${ }^{5}$.

Es esa falta de estudios la que ha hecho de la Procuración/Gobernación catalano-aragonesa, una magistratura poco conocida más allá de cuestiones generales. La imagen, pues, que tenemos de ella es ciertamente estereotipada y en algunos casos errónea, cuando no confusa, atendiendo a lo reiterado de las apreciaciones, muchas veces seculares, que se han ido incluso deformando a lo largo del tiempo ${ }^{6}$. Pero en el mejor de los casos, nuestros conocimientos acerca de esta institución en los diferentes estados de la Corona de Aragón son fundamentalmente de tipo jurídico y procesal, en el sentido de atribuciones de sus oficiales, y en menor medida de carácter político-social. Además, la Gobernación, como magistratura, contó con una

${ }^{2}$ Autores como G. Pillito, S. Lippi, A. Era, A. Boscolo, B. Anatra, M. Tangheroni, F. C. Casula, L. d'Arienzo, G. F. Fara, A. Solmi, M. Viora, M. Pallone, J. Mateu Ibars, R. Pintus, E. Stumpo, G. P. Tore, L. Caro, G. Todde, A. Marongiu, R. Di Tucci, C. Manca, M. Pinna, E. Putzulu, A. Mattone, etc.

${ }^{3}$ G. Olla REPETTO, Gli ufficiali regi di Sardegna durante il regno di Alfonso IV, Cagliari, 1969; ID., Il primo "Liber Curiae" della Procurazione reale di Sardegna (1413-1425), Roma, 1974; ID., L'istituto del 'procurator regius regni Sardiniae' sotto Alfonso il Magnanimo, "IX Congreso de Historia de la Corona de Aragón", II, Napoli, 1982, pp. 135-145; ID. L'administració reial, en Els catalans a Sardenya, Barcelona, 1984, pp. 47-50; ID., La storiografia sugli ufficiali regi della Sardegna catalano-aragonese e la nascita dell'istituto del governatore nella Corona d'Aragona, "Archivio Storico Sardo", XXXVI (Cagliari, 1989), pp. 105-127.

${ }^{4} \mathrm{M}^{\mathrm{a}}$.M. Costa I PARETAS, Dades sobre els governadors de Sardenya en temps de Pere el Cerimoniós, "VII Congreso de Historia de la Corona de Aragón", Barcelona, 1962, II, pp. 355367; ID., Oficials de la Corona d'Aragó a Sardenya (segle XIV). Notes biogràfiques, "Archivio Storico Sardo", XXIX (Cagliari, 1964), pp. 325-377; ID., Sobre uns pressupostos per a l'administració de Sardenya (1338-1344), "Homenaje a Vicens Vives", I, Barcelona, 1965, pp. 395-415. ID., Oficials de Pere el Cerimoniós a Sàsser (1336-1387), "Comunicazione al 10 Convegno internazionale di studi geografico-storici. La Sardegna nel mondo mediterraneo" (Sassari, 1978), pp. 289-314.

${ }^{5}$ J. LALinde ABAdía, La Gobernación General en la Corona de Aragón, Zaragoza, 1963. Referencia de conjunto sobre el mismo tema en M.A. LADERO QUESADA, El ejercicio del poder en la Corona de Aragón: Instituciones e instrumentos de gobierno (siglos XIV y XV), "En la España Medieval", 17 (Madrid, 1994), pp. 51-53.

${ }^{6} \mathrm{E}$. SAlvador Esteban, La Gobernación valenciana durante la Edad Moderna. Cuestiones en torno a su singular estructura territorial, "Studia Storica et Philologica in Honorem M. Batllori" (Roma, 1984), p. 443. 
Curia o tribunal en el que junto al gobernador, como oficial superior, se adscribían otros cargos imprescindibles para su funcionamento. E igualmente de ellos conocemos sólo, en los pocos casos estudiados, nombres, salario y atribuciones, pero siempre desde la aséptica perspectiva que nos ofrece la documentación administrativa, que lógicamente no entra a tratar aspectos de funcionamiento cotidiano.

Con este pequeño artículo pretendemos mejorar los conocimientos acerca de la institución cuyos estudios vindicamos desde precisamente esa última óptica, la de funcionamiento cotidiano de los oficiales de la Gobernación en un territorio concreto, Cataluña.

Apuntando ya su fin el Trescientos, el por entonces gobernador de Cataluña, Ramon Alemany de Cervelló, dispuso la elaboración de unas Ordenanzas para el correcto desempeño de todos los oficios vinculados a la institución que regía, incluido el suyo. Las razones, exponía, no eran otras que un mejor servicio a la ciudadanía evitando, entre otras cosas, la demora en la ejecución de los procesos. Con tan noble fin, y a solicitud e instancia del rey, Ramon Alemany de Cervelló presentó en mayo de 1399 un documento en forma de cuaderno, que tras ser refrendado por Martín el Humano el 24 de ese mes había de convertirse en el modelo procedimental de todos los oficiales de la Gobernación, incluido como decimos el propio gobernador. La importancia del documento es manifiesta. No desde luego porque tal estatuto viniese a perfilar el panorama de las competencias de la Gobernación catalana, que como la aragonesa o la valenciana nació y se desarrolló con un componente de arbitrariedad muy elevado en su desempeño. Más bien su importancia radica en que es el primer intento de regulación que conocemos en el desempeño directo de todos los cargos que hacían funcionar la maquinaria gubernativa del Principado. Como observaremos, no se trataba de perfilar atribuciones, lógicamente conocidas por los regentes de cada oficio, sino apuntar cómo debía ejercerse el cargo, qué hacer en determinados momentos y al respecto de determinadas cuestiones tocantes a su ámbito competencial.

En cuanto a su autor, quizá nadie mejor que él para llevar a cabo una misión en la que se necesitaba un conocimiento puntual de los mecanismos procesales y ejecutivos de la magistratura. Nadiemejor que él, decimos, porque su autor, el noble catalán Ramon Alemany de Cervelló, en esos 
momentos llevaba casi cuatro décadas al frente de ese oficio en distintos territorios de la Corona, sin contar sus servicios al rey que datan desde los inicios de la guerra con Castilla de mediados de siglo ${ }^{7}$. Quien ya en 1360 actuaba en calidad de consejero de Pedro el Ceremonioso ${ }^{8}$, al año siguiente alcanzaba la Gobernación de los condados del Rosellón y la Cerdaña y la castellanía del castillo de Perpignan'. En octubre de 1370 pasó a regir los destinos de la Gobernación del reino de Valencia ${ }^{10}$, oficio que abandonó a los cuatro años para regresar a su tierra y hacerse cargo de la institución homónima en Cataluña" ${ }^{11}$. Durante su dilatada vida al servicio de la Corona, y como señala F. Sabaté, ni las sucesiones al trono ni los avatares políticos le alejaron del ejercicio del poder ${ }^{12}$. Ni siquiera truculentos asuntos personales, cuando en 1380 fue acusado junto a Roieto de Xuera, camarero y doméstico del rey, de sodomía y exculpado por Pedro IV de tal acusación ${ }^{13}$. A pesar de alguna acción poco lícita ${ }^{14}$, su ascendente sobre la familia real le permitió que primero un hermano y luego su propio hijo le sucedieran en la Gobernación catalana ${ }^{15}$.

Por todas estas razones, basadas en el conocimiento y la experiencia en el ejercicio del oficio, Ramon Alemany de Cervelló era la persona idónea para redactar unas ordenanzas que en cuanto reglamento interno sirviesen para hacer más operativa a la magistratura, al alcanzar a todos los miembros de la Curia Gubernationis. Nueve son los oficios tratados por el gobernador

\footnotetext{
7J. ZURITA, Anales de la Corona de Aragón, 4, Zaragoza, 1978, Libro IX, cap. VI, p. 311.

${ }^{8}$ ACA, C, reg, 1072, f. 120r.-v. (1360, agosto, 13).

${ }^{9}$ Por el desempeño de ambos oficios recibiría la cantidad de seiscientas libras barcelonesas anuales, quinientas por el primero y cien por el segundo. ACA, C, reg. 969, f. 68r.-v. (1361, diciembre, 28) y ACA, C, reg. 969, f. 76v. (1362, junio, 28).

${ }^{10} \mathrm{ACA}, \mathrm{C}$, reg. 972, f. 147v. (1370, octubre, 31)

"ACA, C, reg. 973, ff. 157v.-158v (1354, octubre, 16). F. SABATÉ I CURULl, La Governació al principat de Catalunya $i$ als comtats de Rosselló y Cerdanya, "Anales de la Universidad de Alicante. Historia Medieval", 12, en prensa.

${ }^{12} \mathrm{M}^{\mathrm{a}} \mathrm{T}$. FERrer I MALLOL, El Consell reial durant el regnat de Martí l'Humà, "XV Congreso de Historia de la Corona de Aragón", Zaragoza, 1996, I/2, p. 184; F. SABATÉ I CURULl, La Governació.

${ }^{13} \mathrm{ACA}, \mathrm{C}$, reg. 1454, ff. 110v.-111r. (1380, febrero, 23).

${ }^{14}$ En octubre de 1384 Pedro el Ceremonioso le condenó junto a su hijo Huguet al pago de una importante cantidad de dinero - 386 libras, 8 sueldos y 2 dineros- junto con los costes del proceso por negar dicha cantidad al mercader barcelonés Bernat Oliver. ACA, C, reg. 1454, ff. $126 \mathrm{r} .-127 \mathrm{v}$. (1384, octubre, 15).

15. J. LALinde ABAdía, La Gobernación General, pp. 315-316; Ma . T. FerRer I MaLLOL, El consell reial, p. 184; F. SABATÉ I CURULL, La Governació.
} 
en los denominados "Capítols e ordinacions fetes per lo noble mossèn Ramon Alamany de Cervelló, governador de Cathalunya sobre lo regiment dels officials de son offici".

\section{EL GOBERNADOR}

Establece el documento que las mañanas de dos días a la semana, martes y viernes, distintos subalternos de la magistratura, a saber, el asesor, el abogado fiscal, el reebedor dels emoluments, el escribano y el procurador fiscal, acudan a la casa del gobernador con el fin de conocer todas las causas y negocios fiscales, tanto criminales como de otra naturaleza, presentadas en ese Tribunal para que sobre ellas se pudiese proceder de forma ordenada. En esos mismos días y en el mismo lugar se faça recitació de tots los dits fets fiscals y así se pueda hacer una relación de los mismos que haga más operativa su resolución. En caso de que por causa de la gran cantidad de asuntos fiscales los citados dos días no fuesen suficientes, habría de habilitarse un tercero, miércoles por la mañana, y después de comer si fuese menester, para que en esos tres días se procediese a conocer todas y cada una de las causas fiscales. De alcanzar esos procesos número tal que resultase imposible ser atendidos por el asesor de la magistratura, o de estar dicho oficial ocupado en otros asuntos que le impidiesen tal menester, quedaría el gobernador encargado de elegir a su arbitrio y voluntad a otros juristas de reconocida aptitud a los que pudiese encomendar esos asuntos, y que de esta forma no se produjese un colapso en la resolución de las causas que redundase en un retardo de la justicia.

\section{EL ASESOR}

Debido a la trascendencia de este oficio en el hecho procesal de la Gobernación, sin cuyo concurso resultaba inviable la resolución de cualquier causa o proceso ${ }^{16}$, se indica en estas ordinacions que el asesor había de acudir diariamente, por la mañana y después de comer, a la casa del gobernador para ahí, y no en otro lugar, tomar y recibir testimonios en las

\footnotetext{
${ }^{16}$ J.V. Cabezuelo Pliego, La Curia de la Procuración.
} 
causas criminales y realizar sus inquisiciones de tal manera que se pudiesen debidamente y sin intervalo proseguir y continuar. Este proceder debía ser idéntico para aquellos otros jueces nominados por el gobernador en las circunstancias arriba referidas.

En el caso de que se llevase a cabo una inquisición con el consejo del asesor o de los jueces elegidos por el gobernador, no pudiéndose en justicia fundamentar ni mantener dicha inquisisión o proceso, y de haberle o haberles sido establecido fianza, el asesor ordinario o los mentados jueces electos habrían de hacer relación de lo sucedido al gobernador para que de estar presos los inculpados fuesen liberados, mientras que de no estarlo por haber satisfecho una cantidad en concepto de fianza ésta quedase cancelada y cualesquiera procesos contra ellos fuesen revocados. Esta resolución se dirigía fundamentalmente para tratar de paliar los daños ocasionados por causas abiertas sustentadas únicamente por una denuncia no contrastada.

Se establece asimismo, para agilizar el desarrollo de los procesos, que dentro de la casa del gobernador el asesor disfrutaría de una estancia donde tener audiencia todas las mañanas, escuchando y haciendo relación de las súplicas de quienes ante él se presentasen. De igual modo queda dispuesto que el asesor pudiese estar presente durante los días destinados a la expedición de los negocios fiscales, siempre y cuando encomendase a otro jurista de reconocida competencia su lugar en la audiencia.

Finalmente, se indica que si ante el asesor o su lugarteniente se presentasen viudas, huérfanos, pobres y cualesquiera otras personas miserables pidiendo justicia, les fuese facilitada lo más brevemente posible. Caso de que por razón de su pobreza no pudiesen pagar a los jueces a quienes encomendasen sus procesos, éstos, sin salario alguno, se ocupasen de tales causas, ya que podrían resarcirse de esa pérdida cuando tomasen otras que les dejaran un buen dinero. En el supuesto de que los citados juristas no quisieran aceptar tales procesos, dispone el gobernador que tampoco les fuesen encomendadas causas de las que pudiesen obtener importantes dividendos.

\section{El ABOGADO FISCAL}

Es misión de este oficial ocuparse de todas las causas fiscales que se presenten en la Curia de la Gobernación. Si bien, previamente el abogado fiscal ha de conocer si la denuncia es correcta, interrogando a los procurado- 
res fiscales y a los propios denunciantes para obtener pruebas que verifiquen su certeza. En caso de observar que las denuncias se realizan con ánimo de difamar y calumniar, lógicamente ha de rechazarlas. Por el contrario, si considerase que estaban conforme a justicia y tenían fundamento habría de aceptarlas. Las ordinacions consideran que en aquellos procesos en los que los propios denunciantes son los testigos de la acusación, los fiscales actuen con diligencia, evitando el testimonio de los acusadores para eludir la posible difamación.

Se establece que el abogado fiscal habrá de examinar de forma diligente todos los procesos e inquisiciones realizados contra los inculpados de delito fiscal, y en caso de que encontrase que la intención del fisco regio no fuese fundada y sí contra justicia, no seguiría el proceso, así como tampoco lo haría el procurador fiscal, habiéndolo de comunicar al gobernador para que los inculpados, presos o con fianza, fuesen eximidos de toda acción.

Se señala asimismo que como en muchas ocasiones personas de condición miserable son acusadas de delitos, no pudiendo éstas, por razón de su pobreza, defenderse correctamente, en este caso el abogado fiscal ha de tener consideración con la situación de la persona inculpada, no precipitando las investigaciones contra ella, antes bien habrá de comunicarlo al gobernador y al procurador fiscal para que éste a su vez haga lo propio al gobernador, y se proceda de tal manera que los inculpados no se vean indefensos ante la administración por razón de su condición económica y se les pueda aplicar justicia de la manera más correcta.

Finalmente se apunta que el abogado fiscal ha de estar presente en los días y horas establecidos en la ordinació e apuntament e execució de los asuntos fiscales junto al gobernador, el asesor de éste, los jueces y otros oficiales de dicho oficio.

\section{EL "REEBEDOR DELS EMOLUMENTS"}

$\mathrm{Al}$ respecto de este oficio se indica que así como en la casa del rey el tesorero es el cap de todos los asuntos fiscales y otros cualesquiera pertenecientes al rey y al fisco regio, dentro de la institución de la Gobernación el receptor ocupa el lugar del tesorero, debiendo conocer esos asuntos fiscales y solicitando tanto a procuradores como a abogados fiscales que actúen conforme a su oficio para que tales causas se ejecuten de forma 
correcta. Debe ser este oficial quien posea los memoriales de todos los asuntos y negocios fiscales acerca de las regalías y preeminencias del rey, quien ha de comunicar los mismos al abogado fiscal y ha de señalar al procurador fiscal que proceda a instancia de ellos, para que de esta forma las regalías queden bien defendidas e ilesas.

Se establece que dicho receptor, todas las mañanas e incluso después de comer, ha de presentarse ante el gobernador fundamentalmente para conocer del trato de las composiciones que se realicen con los inculpados de esos delitos fiscales, esto es para que en esos delitos sobre los cuales debe admitirse composición pecuniaria se proceda de manera diligente y no se estanquen. Asimismo, y en lo tocante a las composiciones, caso de realizarse, el dinero resultante de las mismas irá a parar a sus manos, habiendo de recibir la parte que corresponde al rey y dividirse la parte restante entre el gobernador, su asesor y el resto de oficiales de la Curia.

\section{EL PROCURADOR FISCAL}

Este oficial debe permanecer siempre junto al abogado fiscal. Tiene como función principal llevarle los procesos e inquisiciones y proceder en ellos siempre según éste le aconseje.

Las ordenanzas recogen que el procurador fiscal se habrá de ocupar de los testigos que declarasen en las causas de carácter fiscal, habiendo siempre de estar cerca del asesor y de los otros juristas que interviniesen en esos procesos, de tal modo que por culpa o negligencia del citado oficial los inculpados de tales delitos no sean vejados en sus derechos más elementales y que por tardanza en su actuación esos procesos no queden en suspenso, sino que muy al contrario sean rápidos. Igualmente, en las denuncias que se realizan ante él o en las que él presente ante el asesor o el abogado fiscal, se cuide de que no exista calumnia, y sobre todo se ocupe de escribir los nombres de aquellos que las realizaron, con el fin de que los denunciantes no sean aceptados como testigos, pues en muchas ocasiones se produce que por rencores unos denuncian a otros y aquellos mismos se presentan como testigos.

Finalmente, se considera que el procurador fiscal deberá cada mañana presentarse ante el gobernador para comunicarle todos los asuntos tocantes a su oficio, especialmente los concernientes a personas pobres y 
miserables, para que éstos vean sus causas, en atención a su pobreza, rápidamente solucionadas.

\section{EL ESCRIBANO}

Las ordinacions señalan que el escribano de la Gobernación ha de contar con un número copioso de escribientes aptos para el desempeño de ese oficio, para que per defalliment del escribano o de sus subalternos los asuntos no se retarden de manera alarmante. En esos procesos han de actuar de forma diligente, tanto en los que esperan percibir una importante suma de dinero como en los que no, pues al parecer la experiencia demostraba que por avaricia y codicia se despachaban antes los asuntos que producían altos ingresos dejando arrinconados aquellos de los que sabían que no percibirían nada. En este sentido, y con ánimo de controlar sus ingresos, se establece taxativamente que ni el escribano ni sus escribientes puedan tomar de las escrituras de los procesos civiles o inquisiciones fiscales más de lo establecido en las Cortes de Cataluña. Del mismo modo que este oficial no podrá tomar de las composiciones que se realizaran en la Curia de la Gobernación dinero alguno por razón de sello, sino únicamente aquello que es acostumbrado tomar por la escribanía regia. Y en caso de que el gobernador realizara remisiones graciosas, el escribano no percibiría peculio por razón de sello más de lo que el gobernador arbitrara para esos casos, habiendo el portant veus en ese arbitrio atender a la calidad del crimen y a la condición de la persona o personas que obtuviesen la remisión.

Este oficial habrá de hacer cabreve o memorial donde señale los nombres de todos aquellos que hayan sido beneficiados con una remisión y las cantidades obtenidas por derecho de sello, habiendo de anotar, igualmente, la fecha completa, año, mes y día en que se llevó a efecto la composición.

Habrá de rendir cuentas una vez al año ante el gobernador o ante quien éste quisiere, de todo aquello que hubiese recibido por razón de derecho de sello de esa escribanía, así como de causas civiles y criminales. Entonces, tras entregar al escribano una cierta cantidad que el texto no recoge y que por tanto queda sin establecer, el resto del dinero habrá de ser entregado al rey o a quien él dispusiera.

En último lugar estas ordenanzas obligan al escribano a despachar todos los asuntos correspondientes a personas pobres y miserables que fuesen 
llevados ante el tribunal de la Gobernación. Si por razón de una difícil situación económica no pudiesen pagar lo que les correspondiese, se establece que este oficial pueda tomarles garantía de que en caso de que el resultado del proceso les fuera favorable satisfarían a la escribanía con lo obtenido de la parte contraria. Nada se dice caso de que perdiesen, lo que lógicamente significa que no satisfarían tal gasto.

\section{El ALGUACIL}

Establece Ramon Alemany de Cervelló que el alguacil de su Gobernación no pueda capturar a persona alguna sin mandato del gobernador, de su asesor o de los jueces a los que se les encomendase realizar inquisiciones y procesos fiscales. E incluso de sospechar acerca de la huida de personas que considerase delincuentes, habría de recibir denuncia previa de delitos cometidos por ellos. En cuanto a su salario, éste ha de ser el establecido en las Cortes de Cataluña y no quedar vinculado a los apresamientos que realizase. En el caso de que algunas personas de cualquier ley o estado fuesen capturadas por el alguacil acusadas de diversos crímenes o delitos y de ellos se quisieran defender, y fuesen encontrados sin culpa y por tal absueltos, este oficial no obtenga ingreso alguno, sino únicamente $l o$ morabatí per raó de entrada. Como sucede que en ocasiones el alguacil carga de cadenas y grilletes a los presos para obtener de ellos algún dinero, cada vez que eso suceda habrá de punírsele con la cantidad de 100 sueldos, la mitad de los cuales pasará a poder del inculpado. En este sentido este reglamento recoge que en caso de que se diese muerte a algún inculpado por razón de los crímenes o delitos por él cometidos, el alguacil no perciba sino lo estipulado en la Constitució de Cathalunya.

Se estipula asimismo que en el supuesto de que algún o algunos presos pagasen fianza o fuesen encomendados a cualesquiera bajo pena de cárcel, mientras los dichos inculpados se hayen en manleuta o en la dita comanda el alguacil no podrá percibir nada por razón del carcellatge. Finalmente, se dispone que el alguacil no pueda tomar salario fuera de lo establecido en la Constitució, ni tampoco pueda entrar en los taulells ni a las tahurerías "per demanar alcuna cosa a aquells qui jugaran" ni otras cosas que resulten ilícitas. 


\section{LOS PORTEROS}

Las ordenanzas refieren que comúnmente la Gobernación de Cataluña cuenta con dos porteros, los cuales reciben un salario por la acción de su oficio. Si bien, como en ocasiones ese número resulta insuficiente, pueda el gobernador designar a otros para que sirviesen en tal oficio, y que los emolumentos percibidos por los porteros fuesen divididos entre todos ellos. Todos los porteros, ordinarios y en su caso extraordinarios, habrán de presentarse cada mañana en la casa del gobernador, incluso antes de que éste se hubiese levantado, listos para ejercer su oficio.

De los dos porteros ordinarios con que cuenta la magistratura, uno habrá de estar siempre presente en la audiencia del gobernador para realizar mandamientos, citaciones y otros actos habituales en esa Curia, mientras que el otro, o el resto, han de estar cerca del gobernador y de los jueces que realicen inquisiciones para citar a los testigos y realizar todas las cosas que corresponde a su oficio. Dichos trabajos serán divididos entre los porteros semanalmente.

En lo que respecta a su salario, los porteros únicamente podrán tomar de las citaciones y mandamientos 12 dineros, y aquel o aquellos que tomasen más fuesen puestos en prisión durante una semana, además de restituir lo tomado de forma ilegal, debiendo ser gratuito por esa vez la citación o mandamiento realizado por ese portero. En el caso de que los litigantes que necesitasen realizar citaciones o mandatos tuviesen la condición de miserables, los porteros habrán de prestar sus servicios de forma gratuita. Se establece que las averías a pagar por los inculpados por razón de las composiciones realizadas por el gobernador serán distribuidas según disponga el regente de la Gobernación, estableciendo que cada uno de los oficios que participasen en tales asuntos fuesen remunerados con la parte que les correspondiese, "hauda compensació de treballs e a la condició e facultat de lurs persones"

\section{LOS CORREOS}

Las ordenanzas ponen de manifiesto lo imprescindible de la existencia de un correo en la Curia de la Gobernación, estableciendo que 
quien desempeñe este oficio no tenga vinculación deshonesta con mujer alguna - "fembra en bordell ni en altra manera inhonestament no tinga"-, bajo una pena al arbitrio del gobernador. Establece con buen criterio el gobernador que el citado correo ha de tener su buzón con la señal acostumbrada y todo lo que corresponda a su oficio, para que los asuntos se despachen a la perfección y lleguen a la conclusión que deben. Finalmente, el gobernador dispone como gracia especial que el correo pueda comer en su casa.

Fuera ya de lo establecido a los distintos oficios, este reglamento refiere que con el dinero procedente de las primeras composiciones pecuniarias se ordene fabricar diversos útiles que habrán de ser empleados para la realización de justícies corporals. Tales instrumentos habrán de ser custodiados en la Curia del veguer de Barcelona, en bon loch, y su empleo se hará siguiendo un ceremonial establecido. En este sentido, y para dignificar las justicias corporales, las ordinacions recogen que los capdeguaytas de las ciudades donde los hubiera, bajo pena de perder sus oficios, asistieran a quienes portaran los arneses reales en las justicias, armados y a caballo, aunque tan sólo si el gobernador personalmente hiciese acto de presencia, así como también lo harían los vegueres, sotsvegueres y otros oficiales de las ciudades.

Estos capítulos, cuya duración estimaba Martín I a voluntad suya, presentaban una addenda que apuntaba que si para el mejor funcionamiento de los oficios fuese necesario adaptar nuevas disposiciones no contempladas en las ordenanzas, el gobernador tendría facultad para imponerlas en la forma que creyese conveniente. La operatividad, pues, de la magistratura quedaba garantizada. 


\section{APÉNDICE DOCUMENTAL}

1399, mayo, 24. Zaragoza

Martín I señala a Ramon Alemany de Cervelló, consejero, camarlengo y gobernador de Cataluña, asi como al asesor, escribano, alguacil, procurador fiscal, porteros y otros oficiales de la Curia de la Gobernación catalana, y a sus lugartenientes, que en lo tocante a las Ordenanzas presentadas ante él para el gobierno de esa institución en un cuaderno de papiro, selladas con el sello real, las observen y las hagan observar.

ACA, C, reg. 2243, ff. $80 v-84 v$.

Capítols e ordinacions fetes per lo noble mossèn Ramon Alamany de Cervelló, governador de Cathalunya, sobre lo regiment dels officials de son offici.

Pertany-se a l'offici de governador de Cathalunya posar si mateix e los officials de aquell en ordinació e regla per ço que la justícia sie a les gents, e majorment en les causes fiscals, en lcs quals és major perill breument spatxada e los delats longament no sien detenguts, presos ni per missions fatigats ni puguen per lonch deteniment calúmpnia al·legar. E com specialment càrraga de les dites coses per lo molt alt senyor rey sie donada de posar en bon stament, disposició e regla al dit governador lo dit offici, per què havent a memòria les dites coses e havent consideració que expedient és al dit offici e officials de aquell de fer certes regles e ordinacions ab les quals visquen e.s regesquen, per ço lo dit governador, sotsmetén si mateix a les dites ordinacions e regles, fa e ordona les ordinacions seguents, les quals vol e mana, sots privació de lur officis, a cascú dels officials del dit offici que aquelles serven fermament e inviolable. Guillermus, secretarius.

De l'offici del governador e de les coses qui s'han per ell a fer e explicar

Primerament, vol lo dit governador e ordona que dos jorns de la setmana, ço és lo dimarts e divendres per lo matí, tots negocis civils e altres qualsevol a part posats, lo assessor e advocat fiscal si n'i haurà, reebedor dels emoluments, scrivà e procurador fiscal del dit offici sien en la posada del governador e aquís vejen 
totes les causes e negocis fiscals, axí criminals com de altra natura, en quin punt són, en manera que en aquells se proceesquen ordenadament e per justícia. Guillermus, secretarius.

Ítem, que 1 dit governador los dits dimarts e divendres per lo matí don tot loch en la dita sua posada que tots negocis e fets encara propris, quantsevulla sien arduus e perilloses foragitats, que devant ell e en sa presència se faça recitació e relació de tots los dits fets fiscals, en manera que aquells se apunten e córreguen per lurs jornades tota dilació e execució a part posades. Guillermus, secretarius.

Ítem, que si tanta era la còpia e habundància dels dits fets fiscals, que los dits dos dies, ço és lo dimarts e divendres, no abastassen, a ordinació e a apuntament e a exequció de aquells, a compliment de les coses damundites, que lo dimecres per semblant per lo matí e al després menjar, si mester serà, sie elet a les coses damundites; axí que continuadament en los dits III dies se entena e s'ahje a entendre en los dits actes, fets e negocis fiscals, en tal manera que aquells hajen a exequció e compliment e tarda o triga alguna no puguen pendre. Guillermus, secretarius.

Ítem, que si per aventura, segons damunt dit és, de les dits negocis, actes e fets fiscals tanta era la còpia e habundància que los processos o inquisicions de aquells no poguessen ésser fets o fetes lo assessor del dit offici, ço és que per occupació o per altra manera no puguen dar ço a aquell o a aquells que lo dit governador elegesqa a son arbitre o volentat, certs juristes abtes e de bona fama als quals pugue cometre e comenar los dits actes, fets e negocis fiscals, e que aquells facen los processes e inquisicions dels delats, per ço que la justícia sie de aquells breument feta e espatxada. Guillermus, secretarius. //

Ítem, que $\cdot 1$ governador totes setmanes almenys per una vegada regonega per si mateix o per altre regonèxer faça los presos qui en les presons seran detenguts. E açò per tal com moltes vegades n'i ha qui són pobres e miserables persones, los quals no han negú qui $\cdot 1 \mathrm{~s}$ advoch ni·ls procur, e per aquesta raó stan longament detenguts, presos. E contra aquells, si colpa han, per justícia anant proveesquen, per ço que en lur justícia sien espatxades. Guillermus, secretarius.

De l'offici de l'assessor de la Governació

Offici de l'assessor de gran auctoritat és, per ço vol e ordona lo dit governador que aquell sie personalment tots dies per lo matí e aprés menjar en la casa del dit governador e aquí e no en altre loch prenga e reebe testimonis en les causes criminals e faça ses inquisicions e aquelles continuu en manera que aquelles se puguen degudament e sens intervall proseguir e continuar. Guillermus, secretarius.

Ítem, que 1 dit assessor e jutges demunt dits per lo dit governador elets $\mathrm{e}$ assignats hajen a entendre e entenen continuadament en los dits actes, fets e negocis fiscals e en les inquisicions de aquells faedores en la casa del dit governador ab tota 
cura e sobirana diligència, per ço que aquells puguen venir e vinguen a fi e conclusió. Guillermus, secretarius.

Ítem, que si contra algú o alguns seran feta o fetes inquisició o inquisicions o altres qualsevol processes $o$ anantaments de consell del dit assessor o jutges damunt dits, e los dits processes, inquisicions o enantaments no.s podien o no.s poden per justícia sostenir o fundar, e per aquella raó eren alscuns delats presos o posats en manleuta, que encontinent lo dit assessor o jutges facen relació de les dites coses al dit governador, per ço que aquells presos sien encontinent de les presons soltats o lurs manleutes sien cancel-lats e altres enantaments contra ell fets sien revocats. Car moltes de vegades los dits actes e negocis fiscals per moltes raons no han aquella conclusió que·l fisch ne espere. E per ço los delats no deuen ésser contra justícia agreujats ni calumpniats. Guillermus, secretarius.

Ítem, per ço que la justícia en les causes e fets civils no sie embargada, ans breuments les gents en aquella sien espatxades, ordona e vol lo dit governador que en la sua casa o posada sie elegida e triada una sala o competent cambra en la qual contínuament lo dit assessor tots matins tinga e haje a celebrar la dita audiència e oje les gents e les supplicacions de aquelles e les relacions de les jutges de tots e sengles fets que a aquells seran comanats, si les dites gents requeriran o supplicaran a la dita audiència de lurs fets o processes ésser feta relació. Guillermus, secretarius. Ítem, que si les jornades statuïdes e ordonades per expedició de les negocis, actes e fets fiscals lo dit assessor volrà ésser personalment, que en aquells dies lo dit assessor coman e haje a comanar a qualquier prohom e notable juriste que tinga la audiència e oje les gents e les relacions de lurs fets e processes en tal menera que los negocis hajen bona expedició. Guillermus, secretarius.//

Ítem, que si devant lo dit assessor o lochtinent de aquell vindran vídues, pubills, pobres o altres miserables persones demanants justícia de algú o de alcuns, que aquelles e aquells breuments spatxats sien. E si per aventura per lur probrea o necessitat no havien de què pagassen los jutges als quals seran lurs causes comeses o qüestions, que aquells sens tot salari hajen lur justícia los dits jutges spatxar, car comportar poran los fets de les dites vídues e miserables persones ab altres fets de què hauran grans salaris. E si cars serà que $\cdot 1$ dits juristes les causes de les dites persones pendre o espatxar no volien, que no $\cdot$ ls sien fetes comissions de les causes de les quals esperassen haver fruyts o salaris. Guillermus, secretarius.

De l'offici de l'advocat fiscal

Per ço com de les causes, actes, fets e negocis fiscals és càrrega de l'advocat fiscal, ordona lo dit governador que 1 dit advocat fiscal ab gran diligència e $a b$ assiduós treball entena en aquells, ordonant en tots e sengles processes o inquisicions, axí contra los delats com en totes les altres coses, negocis e fets fiscals, en tal manera que per colpa del dit advocat fiscal no.s perda sitiada o jornada en 
aquells, ans tots altres actes jaquits e a part posats entena a bon espatxament de aquells. Guillermus, secretarius.

Ítem, que com les gents moltes e diverses vegades per males e calumpnioses denunciacions sien vexades, calumpniades e contra justícia agreujades, ordona lo dit governador e vol que 1 dit advocat fiscal, lo qual deu preservar les gents de la dita calùmpnia, interroch $a b$ sobirana diligència los procuradors fiscals e altres denunciants si les coses denunciades són veres ne stan en veritat, e si aquelles se poran provar e ab quins e quals testimonis. E si veu que les dites coses se facen per calùmpnia e no hajen fundament, que aquells e aquelles don repulsa. E si veu que les dites coses proceesquen de justícia e hajen fundament, que en ordinació e execució de aquelles entena ab sobirana diligència en manera que en aquelles justícia puga ésser administrada. Guillermus, secretarius.

Ítem, que com moltes vegades per juxa, rancor, mala volentat se facen e·s donen denunciacions contra les gents e los donants aquelles se offiren fer testimoni en les dites causes que aytals denunciadors no sien reebuts ni presos en testimoni, ans lo dit advocat fiscal aytals persones sien esquivades, desenganades e de tots els dits actes foragitades. Guillermus, secretarius.

Ítem, que 1 dit advocat fiscal los processes e inquisicions fets o fetes contra los delats o altres persones regonega e examín ab sobirana diligència, e si veu e coneix en sa consciència que la intenció del fisch no sie fundada e la part de la Cort ne esperas caure, que d'aquí avant per ell o per lo procurador fiscal no y fos procehit ni anantat, // ans encontinent si major fundament dels dits actes no speravan ho diga al dit governador, en manera que los delats qui presos seran sien deliurats o lurs manleutes los sien cancel·lades. Guillermus, secretarius.

Ítem, que com moltes vegades se seguesca e s'esdevenga que algunes pobres persones són de crims delades, en tant que per lur probresa dels dits crims o delacions no.s poden defendre e la part del fisch comunament sie copiosa de advocats, procuradors fiscals, scrivans e altres officials e ministres, que en aquell cars lo dit advocat fiscal haje de aquestes coses consideració, no precipitant les dites inquisicions, faent relació al dit governador e donant càrrega al procurador fiscal de parlar de les dites coses ab lo dit governador que sobre les dites coses proveesqua, en tal manera que los dits delats per lur pobrea no romanguen indefeses ni lur justícia no romanga periclitada, ans aquella los sie administrada. Guillermus, secretarius.

Ítem, que 1 dit advocat fiscal haje ésser present en los dies e hores assignats e ordenats en la ordinació e apuntament e execució de les actes, fets e negocis fiscals ensemps ab lo governador, assessor, jutges e altres officials del dit offici. Guillermus, secretarius. 
De l'offici del reebedor dels emoluments de la Governació

Axí com en la casa del senyor rey lo tresorer és cap de tots e sengles fets fiscals e altres qualsevol pertanyents al senyor rey e a son fisch, axí en lo offici de la Governació lo dit reebedor qui és en loch de tresorer deu haver gran cura e diligència de tots e sengles actes, fets e negocis fiscals, sol-licitant lo advocat e procuradors fiscals que espatxen tot ço e quant se pertany a lur offici, en manera que ls dits negocis hajen bona expedició e vinguen a exequció. Guillermus, secretarius.

Ítem, que 1 dit reebedor ab sos memorials de tots los fets e negocis fiscals o fets qui toquen les regalies o preheminències del dit senyor comunich de e sobre aquells ab l'advocat fiscal del dit offici e que en aquells faça fer al procurador fiscal gran instància, encarregant lo dit advocat fiscal de les dites coses en manera que les regalies del senyor rey sien ben deffensades, mantengudes e de tot sinistre preservades. Guillermus, secretarius.

Ítem, que 1 dit reebedor tots matins e encara los deprés menjars sie ab lo dit governador comunicant ab aquell de tots los dits fets e del tractament de les composicions qui-s mouen per los delats, en manera que les dites composicions que de les actes e fets qui-s deuen admetre a composició sien encontinent espatxades e que per negligència los fets no romanguen embassats. Guillermus, secretarius.

Ítem, que quant alsgunes composicions seran fetes de qualsevulla quantitats sien, que encontinent que-ls dits diners pervendran en mans del dit reebedor, acurant-se la part tanyent al senyor rey, l'altra partesca entre lo dit governador, assessor e altres officials del dit offici, en manera que tots ab gran diligència treballen en aquells. Guillermus, secretarius.//

De l'offici del procurador fiscal

Lo procurador fiscal deu tenir a prop lo advocat fiscal del dit offici portantli los processos e inquisicions per regonèxer aquells e per posar aquells en ordinació e procehir en aquells segons que 1 dit advocat fiscal al dit procurador consellarà. Guillermus, secretarius.

Ítem, que quant los processes e inquisicions o altres fets correran en deffensions $\mathrm{e} \cdot \mathrm{s}$ menaran ordinàriament, que $\cdot 1$ dit procurador fiscal ab sobirana diligència tinga a prop les assignacions e cobre los dits processes o inquisicions dels scrivans apportant-los al dit advocat fiscal qui pos e ordon en aquells en manera que per colpa o negligència del dit procurador fiscal en aquells no $s$ perda jornada $o$ sitiada. Guillermus, secretarius.

Ítem, que 1 dit procurador fiscal ab sobirana diligència se haje en administració dels testimonis que fan a produhir en los processes, inquisicions o altres fets fiscals, tinent a prop lo assessor e altres juristes qui en les dites inquisicions o processos entrevendran e aquells o aquelles faran, $\mathrm{e}$ açò portant que per colpa o negligència del dit procurador fiscal los delats no sien vexats e per tarda 
sua los dits processos e inquisicions no stiguen en sospès, ans tots temps córreguen en lurs dilacions e en lo spatxament de la justícia. Guillermus, secretarius.

Ítem, que 1 dit procurador fiscal en les denunciacions que li seran donades o ell darà als assessors o al dit advocat fiscal que guart no sien calumpnoses e sobre tot scrivà lo nom de aquelles qui les dites denunciacions daran, per ço que los denunciants no sien reebuts en testimonis, car moltes vegades se seguex que per malvolences, oys, rancós alsguns denuncien e acusen altres e aquells mateix fan testimoni contra aquells, la qual cosa seria alt e fort reprovada. Guillermus, secretarius.

Ítem, que 1 dit procurador fiscal tots matins sie devant lo governador faentli e reduhint-li a memòria tots los fets fiscals e especialment aquells dels pobres $\mathrm{e}$ miserables persones, per ço que aquells en lur justícia breument sien espatxats e espatxades. Guillermus, secretarius.

De l'offici del scrivà de la Governació

L'escrivà de la Governació deu haver còpia e habundància de bons scrivents abtes e sufficients, en manera que per defalliment del dit scrivà e scrivans de aquell los fets no sien tardats ne dilatats e en aquells entenen ab gran cura, axí bé en los fets dels quals no esperen haver fruyts, com en aquells de què esperen haver grans emoluments, com moltes vegades se esdevé e speriència açò mostra que per avarícia e cupdícia los fets dels quals speren haver profit espatxen e los altres romanen e penjen sens algun procehiment. Guillermus, secretarius.//

Ítem, que $\cdot 1$ dit scrivà se guart que dels processes civils e inquisicions fiscals ni los scrivents de aquell no prenguen de scriptures sinó segons és estat tatxat e ordenat en les Corts de Cathalunya. Guillermus, secretarius.

Ítem, que 1 dit scrivà no prenga ni gos pendre de les composicions qui $\cdot \mathrm{s}$ faran en lo offici de la dita Governació per raó de segell de les remissions que obtindran, sinó aytant com se'n prenia e és acostumat de pendre liura en la scrivania del senyor rey. Guillermus, secretarius.

Ítem, que si lo governador farà remissions gracioses, que 1 dit scrivà per rahó de segell de aquelles no prenga ni puga haver sinó aytant com per lo governador en los dits cases serà arbitrat o tatxat; lo qual dit governador en lo dit arbitrament o tatxament deu haver consideració a la qualitat del crim e a la condició de les persones qui les dites remissions obtindran. Guillermus, secretarius.

Ítem, que 1 dit scrivà haje a fer capbreu o memorial en los quals meta o scriva los noms de aquells qui les dites remissions obtindran e les quantitats que n'aurà haüdes per dret de segell, e açò sots los kalendaris de l'any, mes e dia en los quals les dites composicions seran fetes e atorgades. Guillermus, secretarius.

Ítem, que 1 dit scrivà tots anys una vegada haje a donar e retre compte al dit governador o a aquell qui ell volrà de tot ço e quant haurà reebut per rahó de segell de la dita scrivania, axí de causes criminals com de civils. E donat al dit 
scrivà ....... barchinonenses per son salari tot l'altre sie restituït al senyor rey o a qui ell volrà. Guillermus, secretarius.

Ítem, que-l dit scrivà haje a espatxar tots e sengles fets de pobres e miserables persones qui en la dita Cort se manaran sens que no n'haje res; si aquells, emperò, són axí pobres que pagar no puguen, puga haver emperò, caució de les dites persones; que si per rahó dels dits plets alguna cosa per justícia aconseguiran, que en aquell cas paguen lo dit scrivà tot ço e quant a ell per justícia se pertanga. Guillermus, secretarius.

De l'offici de algutzir de la Governació

Ordona lo governador que l'algutzir de son offici no prenga ni gos pendre algunes persones si, donchs, no li u mana lo governador, son assessor o jutges dipputats a fer les inquisicions o processes fiscals o no trobava alscuns barallants o alscuns vagabunts dels quals fos sospita de fuyta e ladonchs li fos denunciat aquells ésser delats de leixs e enormes crims. Guillermus, secretarius.

Ítem, que·l dit algutzir no prenga ni gos pendre per rahó de les dites presons o carcellarie sinó aytant com és estat ordonat e tatxat Corts de Cathalunya. Guillermus, secretarius.//

Ítem, que si algunes persones de qualsevol ley o estament sien seran preses alsguns crims o delictes e aquells se volran deffendre e, trobats sens colpa dels dits crims, per justícia seran absolts, que l'algutzir de aquells no haje carcellarie algú, sinó lo morabatí raó de entrada. Guillermus, secretarius.

Ítem, que com los algutzirs moltes e diverses vegades, per haver diners de aquells qui són delats e presos, aquells oppremen ab cadenes o grillons, ordona lo dit governador que si lo dit algutzir d'aquí avant per traure los dits ferres o grillons pendrà diners, que per cascuna vegada cayguen en pena de cent solidos que contrafarà, dels quals la meytat sie dels delats, per la dita raó haurà diners presos. Guillermus, secretarius.

Ítem, que si algun delat de qualsevol ley, stament o condició sie per rahó dels crims dels quals serà delat pendrà mort, que 1 dit algutzir de aquells no haje res sinó aytant com per Constitució de Cathalunya és estat ordonat. Guillermus, secretarius.

Ítem, que si alguns presos o pres serà o seran dats a manleuta o comanats algú o alguns sots pena de carceller, que en aquells cars lo dit algutzir de aquells stant en manleuta o en la dita comanda no haje res per raó de carcellatge. Guillermus, secretarius.

Ítem, que 1 dit algutzir no haje ni gos pendre per inventaris o invocacions alguna cosa de salari, com sie contra constitució, ni encara gos anar per taulells ni per tafuraries per demanar alguna cosa a aquells qui jugaran ni altres coses qui il-licites sien, ans lo abus ara servat del tot sie tolt en aquelles. Guillermus, secretarius. 
De l'offici dels porters de la dita Governació

Comunament en lo dit offici dos porters són ordonats e aquells prenen quitació, los quals en moltes ciutats, viles e lochs en lo servici de aquell no abastan, per què ordona lo dit governador que en los dits cases, si altres porters de manament seu serviran en lo dit offici, que-ls fruyts e emoluments qui a ells se pertanyeran sien partits entre los dits treballants a ordinació del dit governador. Guillermus, secretarius.

Ítem, que-ls dits porters del dit offici, e altres qui en aquell serviran per la forma e rahó demunt dites, tots matins ans que 1 dit governador sie levat sien a la posada de aquell, en manera que sien prests e apparellats a la servitut del dit offici. Guillermus, secretarius.

Ítem, que la I dels dits porters tots temps sie present mentre la audiència del dit governador se tindrà, e aquell faça los manaments, citacions, intimacions e altres actes de la dita audiència, e los altres tinguen a prop lo dit governador e jutges qui faran les dites inquisicions per citar testimonis e fer altres coses qui a lur offici se pertanga. E açò-s partesquen los dits porters a setmanes. Guillermus, secretarius.//

Ítem, que los dits porters de citacions o manaments no gosen pendre sinó XII diners, e qui lo contrari farà stiga pres tota una setmana e sie tengut de restituir a aquell ço que de més pres li haurà. E encara les dites citacions e manaments haja a fer franchs aquella vegada. Guillermus, secretarius.

Ítem, que los dits porters tots temps que per pobres o miserables persones litigants o havents a fer en la dita Cort seran requests de fer algunes citacions o manaments, que aquells o aquelles haje a fer franchs sens dilació e paga alguna. Guillermus, secretarius.

Ítem, que les averies qui·s pagaran per los delats per rahó de les composicions qui.s faran ab lo governador, que sien distribuïdes en la forma e manera que 1 dit governador ordonarà e volrà, axí que cascuns de aquells qui en los fets dels quals exiran les dites averies hauran treballat sien remunerats de aquelles, haüda compensació de treballs e a la condició e facultat de lurs persones. Guillermus, secretarius.

Ítem, que si en lo regiment dels dits officis exiren alsgunes coses qui adaptar fessen, dels quals special menció en los preinserts capítols e ordinacions no fos feta, que 1 dit governador en aquell cas pos e ordon aquelles en la forma e regla que ben vist serà. Guillermus, secretarius.

En lo dit offici de la Governació un correu hi és necessari, per què ordona e vol lo dit governador que aquell fembra en bordell ni en altra manera inhonestament no tinga, e si lo contrari fa que haje per pena ço que 1 dit governador en esmena de sa correcció divisarà ésser sostenidor. Vol, emperó, lo dit governador 
que per ço que-l dit correu sie diligent en la servitut del dit offici, sie quitat bé e complidament lo reebedor de aquell, e principalment que haje sa bústia ab lo senyal acostumat e tot ço que mester li sie, en tal forma que los fets hajen bon espatxament e la conclusió que deuen. E que de gràcia special lo dit governador vol que menge en casa sua. Guillermus, secretarius.

Ítem, que per ço com les justícies criminals qui dins la ciutat de Barchinona e per tot lo principat de Cathalunya se fan, los officials qui les fan vulles que no sien algutzir seu, veguer, sotsveguer o altres officials e saigs van desordonadament en aquelles, ordona lo dit governador que d'ací avant sie axi que primerament ací en la ciutat de Barchinona de les primeres composicions que hic exiran vulles que les faça lo dit governador, veguer o batle, sien fetes XII paveses e uns bells lances e XII ezcones, XII lauders e XII caperons reyals, los quals sien posats en la Cort del veguer de Barchinona en bon loch, en guisa que tota vegada que justícies corporals se faran los dits saigs, entró en nombre de XII, porten los dits paveses, azcones, lauders e caperons, e que vajen entorn de aquells qui serà comdempnat e que no y lexen acostar negú sinó aquell qui $\cdot 1$ confessarà, ni d'aquí $\cdot s$ pertesquen tro que acabadament la justícia sie // feta. E que lo saig qui tromparà toch la trompeta sens panó e en la forma ocostumada, cridant tots temps davant aquell qui comdempnat sie "qui aytal farà aytal pendrà". E feta la dita justícia los dits paveses, lances, lauders e caperons tornen en son loch, en guisa que stiguen areladament e preses a la servitut damundita, en altra manera de les dites arneses negú no·s plevesque. E semblant ordinació sie feta totes les vegueries de Cathalunya, en manera que's regesquen totes aquelles en la forma que és dessús specificat. E si los dits saigs en les dites vegueries no eren en tan nombre que aytants com n'i haje, en lo dit cars vajen en la forma dessús dita. Guillermus, secretarius.

Ítem, que los cap de guaytas de les ciutats on n'aurà sien presents, sots privació de lurs officis, ensemps ab aquells qui los dits arneses reyals portaran en les dites justícies, armats e a cavall, en forma que aquelles se facen honorablement e en la forma que·s pertany. Axí bé si lo governador personalment hi serà com encara los veguer, sotsveguer o altres officials de les ciutats damunt dites.

Plaent al senyor rey les dites ordinacions que duren aytant com a la sua senyoria plaurà, e no en altra manera ni en plus. Matias, vicecancellarius.

Dominus rex mandavit mihi, Guillermo Poncii.

Probata.

Martinus, et cetera, nobili et dilecto consiliario et camerlengo nostro Raymundo Alamany de Cervilione, militi, gubernatori Cathalonie, necnon assessori, scribe, algutzirio, procuratori fiscali ac portariis et aliis ministris et officialibus dicti Gubernacionis officii et dictorum officialium locatenentibus, salutem et dileccionem.

Quia in ordinacionibus noviter su regimine, usu et direccione officii dicte Gubernacionis et aliorum ministrorum et officialium premissorum vos, dictum 
nobilem, nobis missis multa quoque laudabilia, multa utilia et nostris sensibus gratiuta contineri cernimus extensum iubemus, vobis et singulis vestrum quatenus iamdictas ordinaciones in quodam quaterno papiri descriptas et sigillo nostro secreti munitas iuxta sui seriem quandiu nobis placuerit seu aliud a nobis contrarium mandatum habueritis, observetis et faciatis firmiter servari contra dictores et inobedientes ad ea remedia debita compescendo.

Data sub nostro sigillo secreto, Cesarauguste, XXIIII ${ }^{\mathrm{a}}$ die madii, anno a nativitate Domini M CCC XCVIIII ${ }^{a}$. Matias, vicecancellarius.

Dominus rex mandavit mihi, Guillermo Poncii.

Probata.

\section{RÉSUMÉ}

Avec cet article nous cherchons améliorer les connaissances sur une institution d'implantation territoriale, la Gobernación de la Catalogne médiévale, dès d'une perspective de fonctionnement quotidien de ses oficiers.

\section{SUMMARY}

With this article, we intend to improve our knowledge about a territorial implantation institution: the medieval Catalonian Government, from the point of view of its officers daily function. 